\title{
The Study of Intra-Operative Difficulties in One Repeat Caesarean Section Compared with Two or More Caesarean Sections
}

\author{
Arjumand Bano $^{1}$, Aithagoni Srikavya ${ }^{2}$ \\ 1,2 Department of Obstetrics and Gynaecology, Chalmeda Anand Rao \\ Institute of Medical Sciences, Bommakal, Karimnagar, Telangana, India.
}

\section{ABSTRACT}

\section{BACKGROUND}

Most commonly done obstetric procedure globally is caesarean section. The incidence of $\mathrm{C}$-section is continuously increasing because risk associated with vaginal delivery after caesarean, previous caesarean section is an important indication for Csection. The purpose of this study was to assess the difficulties during intra-operative period in women who undergo caesarean section repeatedly and also to study the comparison between difficulties with women with previous one caesarean section and women with previous 2 or more C-sections.

\section{METHODS}

It is a prospective observational study conducted on 150 women in the Department of Obstetrics \& Gynaecology in Chalmeda Anand Rao Institute of Medical Sciences, Karimnagar in women with history of previous caesarean sections (one or more). The women were divided into two groups - Group 1 - Those with previous one caesarean section and Group 2 - Those with previous two or more caesarean sections.

\section{RESULTS}

Out of 150 cases randomly selected and studied who had repeated caesarean section,90 had 1 previous lower segment caesarean section (LSCS), 60 had two or more caesarean sections, the highest number of caesarean sections were performed on women between the age group of 20 - 29 years. Out of these, some cases did not show intra-operative complications, some showed variety of intra-operative complications. Most common type of complications that they came across were adhesions ( $44 \%$ ) in 1 previous LSCS, $65 \%$ in 2 or more LSCS. There were no cases of scar rupture, uterine rupture, bowel injury, caesarean hysterectomy in the study population, probable reason could be that cases were taken elective or taken with a short trial of labour with high level of intrapartum monitoring.

\section{CONCLUSIONS}

Higher incidence of intra-operative complication is seen in women with previous caesarean sections.

\section{KEY WORDS}

Repeat C - Section, Adhesions, Intra-operative Complications
Corresponding Author: Dr. Aithagoni Srikavya, D/o Aithagoni Srinivas, H. No 2-3-487/A/1, First floor, Golden Mansion, Road no 3, Sai Nagar Colony, Nagole, Hyderabad, Telangana,

India.

E-mail: srikavyaaithagoni5@gmail.com

DOI: $10.14260 / \mathrm{jemds} / 2021 / 560$

How to Cite This Article:

Bano A, Srikavya A. The study of intraoperative difficulties in one repeat caesarean section compared with two or more caesarean sections. J Evolution Med Dent Sci 2021;10(33):2745-2748, DOI: $10.14260 /$ jemds/2021/560

Submission 14-10-2020,

Peer Review 11-06-2021,

Acceptance 19-06-2021,

Published 16-08-2021.

Copyright (C) 2021 Arjumand Bano et al. This is an open access article distributed under Creative Commons Attribution License [Attribution 4.0 International (CC BY 4.0)] 


\section{BACKGROUND}

Most commonly done obstetric procedure globally is caesarean section with continuous increase incidence in last two decades leading to the obstetric status "previous caesarean section". India is experiencing a rapid increase in caesarean section delivery along with an increase in institutional deliveries and growing access to gynaecological and obstetric care. ${ }^{1}$ Most of the patients with previous caesarean section undergo repeat caesarean section because of increased complications associated with vaginal birth after caesarean (VBAC). ${ }^{2}$ The factors contributing to high caesarean delivery rate in the developed countries include small family norms, elderly primigravida's, reduced incidence of forceps and vacuum deliveries, increased induction rates, maternal requests, previous caesarean scar, fear of litigation in medical practice. There are many types of caesarean section. An important distinction lies in the variety of incision (whether it is longitudinal or transverse) which is made on lower uterus apart from skin incision site.

\section{Based on Incision}

The classical caesarean section, in which a midline vertical incision is given and this incision allows a larger space to deliver the baby. The lower uterine segment section is the procedure that is commonly used recently. It is done by a transverse incision above the edge of the bladder which leads to lesser blood loss and is easy to repair. Lower vertical incision.

\section{Based on Timing}

An emergency/emergent/crash caesarean section is done as an obstetric procedure where there are complications. A planned caesarean (or elective/planned caesarean) where the surgery is planned in advance, is mostly done for medical reasons and most commonly close to estimated delivery date as possible.

\section{Other Types}

A caesarean hysterectomy is the procedure in which uterus is removed after caesarean section in cases where there is intractable bleeding if the placenta could not be separated. Other forms of traditional caesarean section are extra peritoneal c-section and porro c-section. Repeat c-section is done in a patient who underwent previous caesarean section. It is done through the old scar. Both repeat caesarean and trial of labour after caesarean section (TOLAC) carry risks including maternal haemorrhage, infection, operative injury, hysterectomy, and death. The complications include adhesions, dehiscence, scar rupture, haemorrhage and injury to adjacent structures. The study aims to evaluate the incidence and type of intra-operative difficulties in women undergoing repeat caesarean section.

\section{Adhesions}

It is the most common complications encountered. Abdominal or pelvic adhesions are fibrous band like structures that form between the abdominal organs or between the peritoneum and abdominal wall, where trauma induces inflammation and disrupts normal tissue..$^{3,4}$

Adhesions can develop after infections, surgery, and chemical irritation. The normal wound healing process after the injury to the peritoneum involves a complex inflammatory cascade of fibrin deposition, coagulation and influx of inflammatory cells. Adhesion scoring system have been developed to help establish correlation with disease outcomes and guide in management.5,6

Adhesion Score by Myers et al. $2005^{7}$

- Grade - I - No adhesions present

- Grade - II - Adhesions present but no surgery required

- Grade - III - Adhesiolysis was required and there was inability to exteriorize the uterus

- Grade - IV - Adhesiolysis was required prior to delivery

Grading of Adhesion Based on Severity

None - No adhesion

Mild - A filmy vascular adhesion

Severe - A dense organized cohesive vascular adhesion.

\section{Adhesions Can Be Present between the Following Structures}

- Parietal peritoneum and anterior surface of uterus

- Parietal peritoneum and bladder

- Parietal peritoneum and omentum

- Parietal peritoneum and bowel

- Omentum and uterus

- Omentum and utero vesical folds

- Bladder and uterus (dense)

- Bladder and uterus (loose advancement), uterus and small bowel.

\section{METHODS}

This was a prospective observational study conducted in the Department of Obstetrics and Gynaecology in Chalmeda Anand Rao Institute of Medical Sciences, Karimnagar, Telangana. 150 women were included in the study. Pregnant women who were admitted in our hospital with history of previous caesarean section (one or more) and who underwent repeat caesarean section were randomly selected and included in the study for a period of 1 year from June 2019 to June 2020. Pregnant women with any major open abdominopelvic surgeries, multiple pregnancy, polyhydramnios, abruption placenta, and other medical conditions like severe hypertension, jaundice, heart disease, and severe anaemia were excluded from the study.

Age, parity, number of registered cases, number of previous caesarean sections, gestational age, abortions, elective, or emergency procedure were noted. Operative complications included adhesions, haemorrhage, thin lower uterine segment (LUS), scar dehiscence, placenta previa and accrete, scar rupture, caesarean hysterectomy, bladder, or bowel injury. 


\section{Grades of Adhesion Based on Extent}

- $\quad$ None (no adhesions)- 0

- $\quad$ Localised $(<1 / 3$ of site covered $)-1$

- $\quad$ Moderate $(1 / 3-1 / 2$ of site covered) -2

- $\quad$ Extensive ( $>2 / 3$ of site covered) -3

All women in this study were divided into two groups on the basis of number of previous caesarean sections.

GROUP 1 - Previous one caesarean section.

GROUP 2 - Previous two or more caesarean sections.

\section{Statistical Analysis}

The statistical analysis was performed using standard deviation, calculation of percentage and student ' $t$ ' test, $\mathrm{Z}$ test were applied accordingly to calculate $P$ value for any standard significance which was performed by using Microsoft Excel 2010 and Statistical Package for Social Sciences (SPSS software).

\section{RESULTS}

In present study, out of 150 cases of previous sections, 90 (60 $\%$ ) cases were of previous one caesarean section and 60 (40 $\%$ ) cases were of previous two caesarean sections.

\begin{tabular}{|ccc|}
\hline Number of Previous LSCS & $\begin{array}{c}\text { Number of Patients } \\
(\mathbf{N}=\mathbf{1 5 0})\end{array}$ & $\begin{array}{c}\text { Percentage (\%) } \\
\text { Previous 1 }\end{array} 9^{90}$ \\
\hline Previous 2 & 60 & $60 \%$ \\
\hline Table 1. Number of Previous Caesarean Sections \\
\hline
\end{tabular}

Table 2. Shows various intra-operative complication observed with previous caesarean section. This shows that frequency of adhesion is very high among pregnant women with repeated caesarean section

\begin{tabular}{|c|c|c|c|c|}
\hline Complications & $\begin{array}{l}\text { Previous One } \\
\text { LSCS }(n=90)\end{array}$ & $\begin{array}{c}\text { Percentage } \\
(\%)\end{array}$ & $\begin{array}{l}\text { Previous Two } \\
\text { LSCS }(n=60)\end{array}$ & $\begin{array}{c}\text { Percentage } \\
(\%)\end{array}$ \\
\hline Adhesions & 40 & 44 & 39 & 65 \\
\hline Advance bladder & 14 & 15 & 21 & 35 \\
\hline $\begin{array}{c}\text { Thin lower uterine } \\
\text { segment }\end{array}$ & 19 & 21 & 21 & 35 \\
\hline Scar dehiscence & 6 & 7 & 18 & 30 \\
\hline Scar rupture & 0 & 0 & 1 & 2 \\
\hline Excess blood loss & 12 & 13 & 12 & 20 \\
\hline Bladder injury & 0 & 0 & 1 & 2 \\
\hline Bowel injury & 0 & 0 & 0 & 0 \\
\hline Placenta accreta & 0 & 0 & 0 & 0 \\
\hline $\begin{array}{c}\text { Caesarean } \\
\text { hysterectomy }\end{array}$ & 0 & 0 & 0 & 0 \\
\hline \multicolumn{5}{|c|}{$\begin{array}{l}\text { Table 2. Intra-Operative Complications } \\
\text { During Repeat Caesarean Section }\end{array}$} \\
\hline
\end{tabular}

During the study period, the intra-operative complications noted were adhesions of uterus $44 \%$ in 1 previous LSCS, $65 \%$ in 2 or more previous LSCS, advance bladder is $15 \%$ \& $35 \%$ in 1 previous \& 2 or more previous LSCS. The incidence of thin LUS is found in $21 \%$ in those with previous 1 LSCS and $35 \%$ in those with 2 or more previous LSCS. Scar dehiscence 1 caesarean section vs 2 or more caesarean section $-7 \%$ and 30 $\%$ respectively); scar rupture was seen $2 \%$ cases of previous 2 or more LSCS and bladder injury was seen in $2 \%$ cases of previous 2 or more LSCS. The intra-operative complication during caesarean section was the excess blood loss seen $13 \%$ in previous 1 LSCS and $20 \%$ in 2 or more previous LSCS.

\begin{tabular}{|cccc|}
\hline Age & No of Patients & Complications & Percentage \\
$<20$ years & 1 & 0 & 0 \\
$20-29$ years & 142 & 63 & $44.3 \%$ \\
$30-35$ years & 7 & 2 & $28.2 \%$ \\
\hline \multicolumn{3}{|c}{ Table 3. Age Groups and Complications } \\
\hline
\end{tabular}

No of complications were noted to be highest, i.e., out of 142 patients within the age group 20 - 29 years, 63 patients had complications ( $44.3 \%$ ), and out of 7 patients within the age group 30 - 35 years, 2 had complications (28.2 \%)

\begin{tabular}{|ccccc|}
\hline $\begin{array}{c}\text { H/O Caesarean } \\
\text { Section }\end{array}$ & $\begin{array}{c}\text { Total No of Patients ( } \mathbf{n}= \\
\text { 150) })\end{array}$ & $\begin{array}{c}\text { Adhesions } \\
\text { Present Absent }\end{array}$ & $\begin{array}{c}\text { P - } \\
\text { Value }\end{array}$ \\
\hline 1 & 93 & 39 & 54 & $<0.05$ \\
2 & 57 & 36 & 21 & \\
\hline \multicolumn{4}{c}{ Table 4. Association of Number of Previous } \\
Caesarean Section with Adhesion \\
\hline
\end{tabular}

\begin{tabular}{|c|c|c|c|c|c|c|c|c|}
\hline \multirow[b]{2}{*}{ Group } & \multicolumn{4}{|c|}{$\begin{array}{c}\text { Emergency C-Section } \\
\text { (n= 111) }\end{array}$} & \multicolumn{4}{|c|}{ Elective C-section ( $n=39$ ) } \\
\hline & \multicolumn{2}{|c|}{$\begin{array}{l}\text { With } \\
\text { Complications }\end{array}$} & \multicolumn{2}{|c|}{$\begin{array}{l}\text { Without } \\
\text { Complications }\end{array}$} & \multicolumn{2}{|c|}{$\begin{array}{c}\text { With } \\
\text { Complications }\end{array}$} & \multicolumn{2}{|c|}{$\begin{array}{c}\text { Without } \\
\text { Complications }\end{array}$} \\
\hline I & 51 & $45.5 \%$ & 40 & $35.3 \%$ & 9 & $22.2 \%$ & 22 & $56.4 \%$ \\
\hline II & 6 & $6.9 \%$ & 14 & $12.3 \%$ & 3 & $7.6 \%$ & 5 & $11.7 \%$ \\
\hline III & 0 & 0 & 0 & 0 & 0 & 0 & 0 & 0 \\
\hline Total & 57 & $52.4 \%$ & 54 & $47.6 \%$ & 12 & $29.8 \%$ & 27 & $68 \%$ \\
\hline
\end{tabular}

\section{DISCUSSION}

The increasing number of deliveries by caesarean section is of high concern. The most common indication that accounts for about one-third of all caesarean sections is delivery of prior child by caesarean section. Intra-operative complications of multiple caesarean section includes significant bleeding scar dehiscence, rupture of uterus, presence if intra peritoneal adhesions, placenta accrete, injury to urinary bladder and hysterectomy. 8,9

It is important to explain women before trial of labour or planned caesarean section regarding the data showing mother's complications during repeat caesarean section. Mother should also be explained of tubal ligation which is a permanent birth control method and also the complications regarding the same.10,8,9

The study includes a greater number of emergency caesarean sections than elective sections, this is because many cases in our study were unbooked that arrived in the hospital for delivery with labour pains that were either referred from higher centre or were unwilling for trial of labour. A large number of cases with prior caesarean section were considered emergency, as antenatal care seeking rate is poor in our country along with high rates of referral to tertiary centre and reporting the case at the last moment.

Adhesions were observed as the most common complication leading to further problems like severe haemorrhage, injury to organs, difficulty and delay in delivering baby, long term complications include chronic pelvic pain. Based on previous number of caesarean sections, the incidence range of adhesions is from $46-65 \%$. Direct proportionality was noted in our study between number of caesarean section and adhesion rate, that is, women with higher number of previous caesarean section had higher chances of developing adhesions. ${ }^{11,12}$ 
It is noted that the incidence of scar dehiscence was $30 \%$. In our study, amongst all cases, only one case of scar rupture was documented. Although caesarean section is performed in the absence of contraction of uterus in women with previous caesarean section, inadequate scar thickness and dehiscence has been noted. This study reveals that women with repeat caesarean section have risk of scar dehiscence up to $30 \%$ and of thin scar as $35 \%$. Other studies revealed direct proportionality between scar dehiscence and caesarean section. ${ }^{12}$

Severe bleeding was noted in the study, though there isn't any statistical difference between the two groups. There was a directly proportional relation between blood loss and number of caesarean sections. Only a single case of bladder injury was noted in women with multiple LSCS which was because of excessive adhesion between bladder and uterus. Injury to bowel is a less observed complication of caesarean section. In contrast to the study, it was noted that increasing number of caesarean sections correlated with peripheral organ damage.

\section{CONCLUSIONS}

Caesarean section is the most commonly performed surgery worldwide. Though its development and application has saved the lives of countless mothers and infants, complications with caesarean section are also increasing. Caesarean section rates are increasing all over the world during the past few decades. Caesarean section has more adverse effects on the mother if it is a primary or a repeat section. As in our study of intraoperative difficulties, in repeat caesarean sections, adhesions, scar dehiscence, scar rupture, placenta accreta are increasing with the increase in the number of previous sections. As the caesarean delivery rates are increasing, efforts are in progress to reduce the incidence of adhesions in repeat caesarean deliveries. If once a woman had caesarean section, she is at risk of repeat caesarean section. Hence primary caesarean section rates have to be reduced whenever possible.

During caesarean delivery, women are at increased risk of injury than they are during a vaginal birth. the risk increases with increase in number of caesarean sections, parity, early marriages, early conception, short intervals, between subsequent pregnancy, undernourishment, inadequate antenatal check-ups, high prevalence of illiteracy and poverty especially in our Indian women. Women with previous caesarean delivery has to be counselled regarding the risk of repeat caesarean delivery well before she plans her next pregnancy. She has to be educated regarding the need of improving her nutrition, usage of contraception to maintain an inter delivery interval of at least 24 months. Hence as a part of obstetricians, effort should be always there to reduce caesarean section rates whenever possible. The caesarean section rates can be reduced, but only when it is accepted by women and society and safely implemented.

Data sharing statement provided by the authors is available with the full text of this article at jemds.com.

Financial or other competing interests: None.

Disclosure forms provided by the authors are available with the full text of this article at jemds.com.

\section{REFERENCES}

[1] Jame KS, Ghosh S. Levels and trends in caesqrean births: cause for cancer? Economic and Political Weekly 2010;45(5).

[2] Phelan IP. VBAC: time to consider. OBG Management 1996;11(8):62-4.

[3] Darmas B. Use of barrier products in the prevention of adhesion formation following surgery. J Wound Care 2008;17(9):405-8, 411.

[4] Diamond MP, Freeman ML. Clinical implications of postsurgical adhesions. Hum Reprod Update 2001;7(6):567-76.

[5] Boland GM, Weigel RJ. Formation and prevention of postoperative abdominal adhesions. J Surg Res 2006;132(1):3-12.

[6] Davey AK, Maher PJ. Surgical adhesions: a timely update, a great challenge for the future. J Minim Invasive Gynecol 2007;14(1):15-22.

[7] Myers SA, Bennett TL. Incidence of significant adhesions at repeat cesarean section and the relationship to method of prior peritoneal closure. J Reprod Med 2005;50(9):659-62.

[8] Sobande A, Eskander M. Multiple repeat caesarean sections complications and outcomes. J Obstet Gynaecol Can 2006;28(3):193-7.

[9] Zia S, Ratique M. Intra operative complications increase in successive number of cesarean sections: myth or fat? Obstet Gynecol Sci 2014;57(3):187-92.

[10] Rashid M, Rashid RS. Higher order repeat cesarean sections: how safe are five or more? BJOG 2004:111(10):1090-4.

[11] Tulandi T, Agdi M, Zarei A, et al. Adhesion development and morbidity after repeat cesarian delivery AM J Obstet Gynaecol 2009;201(1):56.el-6.

[12] Kaplanoglu M, Bulbul M, Kaplanoglu D, et al. Effect of multiple repeat caesarean section on maternal morbidity data from southeast Turkey medical science monitor. Med Sci Monit 2015;21:1447-53. 